\title{
A DNA Polymorphism Discovery Resource for Research on Human Genetic Variation
}

\author{
Francis S. Collins, ${ }^{1}$ Lisa D. Brooks, ${ }^{1,3}$ and Aravinda Chakravarti ${ }^{2}$ \\ ${ }^{1}$ National Human Genome Research Institute, National Institutes of Health (NIH), Bethesda, Maryland 20892 USA; \\ ${ }^{2}$ Department of Genetics and Center for Human Genetics, Case Western Reserve University and University Hospitals \\ of Cleveland, Cleveland, Ohio 44106 USA
}

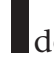
man diseases should become increas ingly feasible with improved methods for finding DNA sequence variants on a genome-wide scale (Collins et al. 1997; Landegren et al. 1998; Wang et al. 1998). To facilitate the discovery of DNA sequence variants, the National Human Genome Research Institute (NHGRI) of $\mathrm{NIH}$, working with the Centers for Disease Control and Prevention, the $\mathrm{Na}$ tional Institute of Environmental Health Sciences, and several individual investigators, has assembled a DNA Polymorphism Discovery Resource of samples from 450 U.S. residents with ancestry from all the major regions of the world. This DNA Polymorphism Discovery Resource will be immensely valuable for the discovery of human genetic variation, which other follow-up studies can relate to health and disease.

Most successes so far in finding genes that contribute to disease risk have been for highly penetrant diseases caused by single genes, such as cystic fibrosis (Kerem et al. 1989; Rommens et al. 1989). To locate genes affecting these rare disorders, researchers perform linkage analysis on families, which requires 300-500 highly informative genetic markers spanning the entire human genome. However, it has been considerably harder to locate the genes contributing to the risk of common diseases such as diabetes, heart disease, cancers, and psychiatric disorders, because these phenotypes are affected by multiple genes, each with small effect; environmental contributions are also important. Instead of linkage analysis on families it may be much more efficient to

\footnotetext{
${ }^{3}$ Corresponding author.

E-MAIL brooks@exchange.nih.gov; FAX (301) 480-2770.
}

perform association analysis on many affected and unaffected individuals, which would require hundreds of thousands of variants spread over the entire genome (Risch and Merikangas 1996). Such a large number of variants is currently not available. The DNA Polymorphism Discovery Resource is designed to promote their discovery.

About $90 \%$ of sequence variants in humans are differences in single bases of DNA, called single nucleotide polymorphisms (SNPs). SNPs in the coding regions of genes (cSNPs) or in regulatory regions are more likely to cause functional differences than SNPs elsewhere. Although most SNPs do not affect gene function, a large number of mapped SNPs will be valuable as markers throughout the genome for finding SNPs that do affect gene function, as linkage disequilibrium over tens to hundreds of kilobases is expected to be found in many regions of the human genome. Both SNPs and cSNPs can be identified by using the DNA Polymorphism Discovery Resource.

When two random chromosomes are compared, they differ at $\sim 1 / 1000$ nucleotides (Kwok et al. 1996). When all chromosomes from 40 individuals are screened, about 17 million SNPs are expected to be found, out of the 3 billion bases in human DNA. Only a small proportion of these SNPs are expected to be in coding regions, as coding regions are $\sim 5 \%$ of the genome and are less likely to have SNPs (Nickerson et al. 1998). Thus the number of cSNPs is estimated to be $\sim 500,000$, an average of about 6 per gene.

There is thus widespread interest in finding SNPs. They are also more numerous, more stable, and potentially easier to score than the microsatellite repeat variants currently used for mapping genes. Given the large potential role of
SNPs in human disease it is important to have these data in the public domain (Heller and Eisenberg 1998). Consequently NIH recently began an initiative for large-scale discovery of SNPs and for improving the technology to detect them. For this initiative, as well as others that are just starting, a common, geographically diverse DNA resource for SNP discovery is crucial, so that researchers can benefit from the cumulative power gained by sharing a common resource, analogous to the demonstrated benefits of the common CEPH panel for genetic mapping and the $\mathrm{RH}$ panels for physical mapping. Accumulating information on the same samples will allow validation, quality control, and comparisons of different methods of detecting SNPs.

The DNA Polymorphism Discovery Resource has been assembled to serve this function. It includes cell lines and DNA from 450 anonymous, unrelated individuals, with equal numbers of females and males. No medical, phenotypic, or ethnicity information is included. There are predefined subsets with $8,24,44$, and 90 samples as well as the complete set, with each subset containing the smaller subsets. The subsets have the same range of diversity as the complete set. This span of sample sizes will allow researchers to use common sets of samples that are of the appropriate size to address various questions. Fewer samples will be needed when researchers are developing new technologies or looking for common variants; however, a more extensive set of samples will be needed when researchers are scaling up technologies or looking for rarer variants.

The sampling strategy for the DNA Polymorphism Discovery Resource facilitates finding genetic variants in the entire human population (Table 1). Any 
Table 1. Composition of the DNA Polymorphism Discovery Resource

\begin{tabular}{|c|c|c|c|c|c|c|}
\hline \multirow{2}{*}{$\begin{array}{l}\text { Population } \\
\text { group }\end{array}$} & \multirow{2}{*}{$\begin{array}{l}\text { Propor. } \\
\text { admix. }\end{array}$} & \multirow{2}{*}{$\begin{array}{l}\text { No. of } \\
\text { indiv. }\end{array}$} & \multicolumn{4}{|c|}{ No. of genomes by continent } \\
\hline & & & Europe & Africa & America & Asia \\
\hline European-American & 0.01 & 120 & 119 & 1 & 0 & 0 \\
\hline African-American & 0.17 & 120 & 20 & 100 & 0 & 0 \\
\hline Mexican-American & 0.39 & 60 & 36 & 5 & 19 & 0 \\
\hline Native American & 0.05 & 30 & 2 & 0 & 28 & 0 \\
\hline Asian-American & 0.10 & 120 & 12 & 0 & 0 & 108 \\
\hline \multirow{2}{*}{\multicolumn{2}{|c|}{ Total no. of individuals }} & 450 & & & & \\
\hline & & & 189 & 106 & 47 & 108 \\
\hline
\end{tabular}

population contains $\sim 85 \%$ of the worldwide genetic variation, but none contains all of it (Barbujani et al. 1997). Because a random sample of U.S. residents would include genomes of mostly European origin, the DNA Polymorphism Discovery Resource includes individuals with non-European ancestry at more than their frequency in the U.S. population, although no attempt was made to be exhaustive or precisely balanced. The individuals sampled are U.S. residents who have ancestors from the major geographic regions of the world-Europe, Africa, the Americas, and Asia (Weiss 1998). Many U.S. residents have ancestors from more than one region, and such individuals are included in the DNA Polymorphism Discovery Resource. The European-American group includes non-Hispanic whites; the African-American group includes nonHispanic blacks; the Americas group includes Mexican-Americans and Native Americans; and the Asian-American group includes individuals whose ancestors came from several countries in East and South Asia.

Table 1 shows the number of individuals sampled from each population group and the expected number of genomes corresponding to the proportion of their ancestry from each geographic region. The second column shows current estimates of the average amounts of admixture for the groups sampled: African admixture for the EuropeanAmericans, Native American and African admixture for the MexicanAmericans, and European admixture for the other groups (Hanis et al. 1991; Parra et al. 1998).

All samples came from individuals who gave informed consent explicitly to be part of this DNA Polymorphism Discovery Resource. The consent forms ex- plain that the purpose of the DNA Polymorphism Discovery Resource is to discover genetic variation. All collection of consents and samples received Institutional Review Board (IRB) approval. For the Native American samples, consent was obtained first from the tribe and then from individuals; in addition, community issues were discussed with other Native Americans and representatives of the Indian Health Service.

To ensure a diverse collection, information on geographic origin and gender was collected for each individual sampled, but once the DNA Polymorphism Discovery Resource was assembled, all identifying and demographic information was removed from the individual samples. Because 52\% more individuals gave consent than were included in the DNA Polymorphism Discovery Resource, no one, not even those sampled, knows which individuals are actually included. A summary of the number of individuals sampled from each group is available for the complete collection and the predefined subsets, but no identifiers are associated with individual samples.

The DNA Polymorphism Discovery Resource was designed to be used to discover variants in human DNA, not to assess the frequency of variants in particular groups. Thus, the DNA Polymorphism Discovery Resource is not useful for population-specific medical or anthropological studies, such as the $\mathrm{Hu}$ man Genome Diversity Project (Committee on Human Genome Diversity 1997). The lack of information on geographic origin and phenotype may be seen by some as a lost opportunity for research. However, many ethical issues are raised by including such information, and addressing these issues will take time. The Ethical, Legal, and Social
Implications research program of NHGRI has made these issues a high priority for consideration; they include avoidance of stigmatization, population definition, community consultation, and education about the meaning of genetic variation. These issues must be addressed so that any potential harmful effects of research on human genetic variation are minimized while the benefits are made widely available. Delay in the development of the DNA Polymorphism Discovery Resource while these issues were being addressed would have resulted in lost research opportunities, so the admittedly limited approach described here was adopted as an initial step in this area.

A concern has been raised that researchers might try to identify the ethnicity of the samples (Foster and Freeman 1998). This probably cannot be done precisely, as most variants occur in most populations, and some individuals have ancestry from multiple regions. Nonetheless, the Native Americans agreed to participate only on the condition that such identification would not be attempted. Consequently, attempting to define the population affiliation of the samples in the DNA Polymorphism Discovery Resource is a violation of the consent form and thus a violation of regulation 45 CFR 46 for the protection of human subjects. Users will be required to agree not to attempt to identify ethnicity when they obtain samples and when they access the data derived from the DNA Polymorphism Discovery Resource in the NIH SNP database (see below).

The samples are available from the Coriell Institute for Medical Research as part of the National Institute of General Medical Sciences Human Genetic Mutant Cell Repository (http://umdnj.edu/ locus/nigms/). The NHGRI, in consultation with the Office for Protection from Research Risks, considers the material in the DNA Polymorphism Discovery Resource to be in the category of human subjects, for which exemption 4 , use of anonymous samples, should apply. All use of material in the DNA Polymorphism Discovery Resource must be reviewed by an IRB and approved or designated as exempt. The Coriell Institute requires that researchers submit their proposed research plans so it can check that the plans are in accordance with the consent forms signed by the indi- 
viduals who agreed to participate in the DNA Polymorphism Discovery Resource.

The NIH National Center for Biotechnology Information has created a database to collect information on all SNPs found for each sample in the DNA Polymorphism Discovery Resource, as part of their SNP database, dbSNP (http:// www.ncbi.nlm.nih.gov/SNP/). SNP discoverers are encouraged to submit their data to dbSNP because a central database will give researchers ready access to data on the variants found using the DNA Polymorphism Discovery Resource as well as the ability to verify the SNP data and to find associations among SNPs.

Finding genetic variants on a large scale is a natural extension of the $\mathrm{Hu}$ man Genome Project and has become one of its new goals (Collins et al. 1998). At least 100,000 SNPs are expected to be discovered in the next 3 years and placed in the public domain. These variants will allow researchers to identify the genetic basis for common diseases and to improve the efficacy of drugs and other therapies.

\section{ACKNOWLEDGMENTS}

We particularly thank the individuals who agreed to participate in the DNA Polymorphism Discovery Resource and the research groups who provided the samples. We thank the participants in the DNA Polymorphism Discovery Resource planning meeting, held at the NIH on December 8-9, 1997, which laid out the blueprint for the plan described here: Kenneth Buetow, Linda Burhansstipanov, Aravinda Chakravarti, Georgia Dunston, Jonathan Friedlaender, Bronya Keats, Charles Langley, Andrew Merriwether, John Moore, Robert Nussbaum, Madison Powers, Nancy Press, Edward Sondik, Karen Steinberg, Diane Wagener, LeRoy Walters, Bruce Weir, and Kenneth Weiss. We also thank Jeanne Beck, Christine Beiswanger, Jean Findlay, William Freeman, Bettie Graham, Judith Greenberg, Mark Guyer, Clifford Johnson, Robert Johnson, Elke Jordan, Cay Loria, Jennifer Madans, Geraldine McQuillan, Glenn Pinder, Edward Sondik, Elizabeth Thomson, and Lorraine Toji for assistance with the project. We thank the National Institute of General Medical Sciences for supporting this project.

\section{REFERENCES}

Barbujani, G., A. Magagni, E. Minch, and L.L. Cavalli-Sforza. 1997. Proc. Natl. Acad. Sci. 94: 4516-4519.

Collins, F.S., M.S. Guyer, and A. Chakravarti. 1997. Science 278: 1580-1581.
Collins, F.S., A. Patrinos, E. Jordan, A. Chakravarti, R. Gesteland, L. Walters. 1998. Science 282: 682-689.

Committee on Human Genome Diversity, National Research Council. 1997. Evaluating human genetic diversity. National Academy of Sciences, Washington, D.C.

Foster, M.W. and W.L. Freeman. 1998. Genome Res. 8: 755-757.

Hanis, C.L., D. Hewett-Emmett, T.K. Bertin, and W.J. Schull. 1991. Diabetes Care (Suppl. 3) 14: $618-627$.

Heller, M.A. and R.S. Eisenberg. 1998. Science 280: 698-701.

Kerem, B.-S., J.M. Rommens, J.A. Buchanan, D. Markiewicz, T.K. Cox, A. Chakravarti, M. Buchwald, and L.-C. Tsui. 1989. Science 245: 1073-1080.

Kwok, P.-Y., Q. Deng, H. Zakeri, S.L. Taylor, and D.A. Nickerson. 1996. Genomics 31: 123126.

Landegren, U., M. Nilsson, and P.-Y. Kwok. 1998. Genome Res. 8: 769-776.

Nickerson, D.A., S.L. Taylor, K.M. Weiss, A.G. Clark, R.G. Hutchinson, J. Stengård, V. Salomaa, E. Vartiainen, E. Boerwinkle, and C.F. Sing. 1998. Nat. Genet. 19: 233-240.

Parra, E.J., A. Marcini, J. Akey, J. Martinson, M.A. Batzer, R. Cooper, T. Forrester, D.B. Allison. R. Deka, R.E. Ferrell, and M.D. Shriver. 1998. Am. J. Hum. Genet. 63: 1839-1851.

Risch, N. and K. Merikangas. 1996. Science 273: $1516-1517$.

Rommens, J.M., M.C. Iannuzzi, B.-S. Kerem, M.L. Drumm, G. Melmer, M. Dean, R. Rozmahel, J.L. Cole, D. Kennedy, N. Hidaka et al. 1989. Science 245: 1059-1065.

Wang, D.G., J.-B. Fan, C.-J. Siao, A. Berno, P. Young, R. Sapolsky, G. Ghandour, N. Perkins, E. Winchester, J. Spencer et al. 1998. Science 280: $1077-1082$.

Weiss, K.M. 1998. Genome Res. 8: 691-697. 
Genome Research 8: $1229-1231$

A DNA Polymorphism Discovery Resource for Research on Human Genetic Variation Francis S. Collins, Lisa D. Brooks, and Aravinda Chakravarti

The URL for the Coriell Institute of Medical Research, which was provided in this article, should be http://locus.umdnj.edu/nigms.

Genome Research 8 (1998)

\section{Author Index}

Because of an error in printing, the first page of the Author Index was unalphabetized. The entire Author Index for 1998 appears on the following pages. 


\section{Author Index, Volume 8, 1998}

Åslund, L., 809

Abajian, C., 195

Acharya, C., 1022

Adamson, A.A., 791

Agarwala, R., 211

Ajioka, J.W., 18

Aksentijevich, I., 1172

Alland, D., 435

Altenhofen, J.L., 404

Alward, W.L.M., 377

Ambros, P.F., 929

Andersson, B., 809

Andersson, L., 399, 826

Angrist, M., 683

Ankener, M., 1022

Ansari-Lari, M.A., 29

Apoltolou, S., 1172

Aravind, L., 1038

Arbieva, Z.H., 404

Arbour, N.C., 377

Assadnia, S., 711

Auburger, G., 1216

Audic, S., 524

Avner, P., 608

Bagherzadeh, A., 135

Bailey, E., 569

Bailey, L.C., Jr., 234, 362

Bairoch, A., 348

Baldock, R.A., 859

Bankier, A.T., 599

Baptista, P.R., 385

Barbon, A., 817

Bard, J.B.L., 859

Barrett, J.C., 666

Baskin, D., 1022, 1131

Beaudet, A.L., 146

Beck, S., 493

Beier, D.R., 9

Belmont, J.W., 29

Belosludtsev, Y., 741

Berkes, C., 354

Bernaola-Galván, P., 916

Berno, A., 435

Bhatt, N.K., 146

Biesecker, L.G., 211

Bird, A.P., 621

Blackman, C., 354

Blake, T., 1172

Boeke, J.D., 464
Boguski, M.S., 168

Boitard, C., 608

Bono, H., 203

Boothroyd, J.C., 18

Boright, A., 1060

Borodovsky, M., 1154

Bortoluzzi, S., 817

Bouck, J., 1074

Bourgade, F., 531

Brãzma, A., 1202

Breen, M., 951

Brignac, S., 741

Brown, S.D.M., 531

Brunialti, A.L.B., 531

Brunk, B.P., 18

Bucan, M., 698

Bumgarner, R.E., 1131

Burke, J., 276

Burmeister, M., 737

Burmeister, R., 741

Byrne, M., 83

Cabin, D.E., 940

Callen, D.F., 1172

Cannata, N., 817

Carlstén, J., 951

Carrasquillo, M.M., 111

Centola, M., 1172

Cercek, A., 1172

Chakravarti, A., 111

Chan, H.M., 135

Chee, M.S., 1142

Chen, E.Y., 557

Chen, L., 1022

Chen, S.-M., 557

Chen, X., 549

Chen, X., 1172

Chen, X., 1172

Chevillard, C., 673

Chinault, A.C., 29, 146

Choo, K.H.A., 81

Chowdhary, B.P., 577

Christensen, B.M., 41

Christian, S.L., 146

Cicila, G.T., 711

Ciufo, S.A., 1131

Claverie, J.-M., 524

Clifton, S.W., 331

Collins, F.S., 1172

Constncia, M., 881
Cook, M.W., 543

Cooper, C., 1022

Cooper, P.R., 48, 57

Cowell, L.G., 124

Crabtree, J., 234

Crane, C.F., 479

Cribiu, E.P., 901

Czihal, R., 842

d'Alessi, F., 817

Danieli, G.A., 817

DasSarma, S., 1131

Davidson, D.R., 859

Davies, A.F., 631

Davies, C., 57

Davis, E., 509

Davis, R.W., 848

Davison, D.B., 276

Davoine, C.-S., 1216

Day, C.D., 57

de Jong, P.J., 57

Dear, P.H., 599

Dear, S., 161, 260, 975

Dearlove, A., 531

Dedhia, N.N., 313

Deming, M.S., 599

Demorest, D.M., 69

Dene, H., 711

Deng, A.Y., 711

Deng, Z., 1172

Desmond, E., 435

Dogget, N.A., 1172

Drenkow, J., 435

Drobniewski, F., 435

Drouot, N., 1216

Dürr, A., 1216

Durbin, R., 161, 260

Duret, L., 348

Dyer, K.D., 599

Easton, J., 929

Edfors-Lilja, I., 826

Efcavitch, J.W., 69

Eichler, E.E., 758, 791

Eisen, J.A., 163

Ellegren, H., 951

Evans, A., 531

Evans, G.A., 57, 741

Ewing, B., 175, 186

Faraco, J., 427

Faust, J., 1131
Ferdig, M.T., 41

Fernando, S., 531

Fingert, J.H., 377

Fischel-Ghodsian, N., 1172

Fischer, S., 234

Fizames, C., 1216

Florea, L., 967

Foley, R., 339

Fontaine, B., 1216

Foster, M.W., 755

Francomano, C.A., 211

Freeman, W.L., 755

Friedman, J.M., 985

Frönicke, L., 577

Funa, K., 826

Gabriel, A., 464

Galperin, M.Y., 779

Ganal, M.W., 842

Garey, J.R., 590

Garner, H.R., 741

Garrett, M.R., 711

Gautheret, D., 524

Gerhard, D.S., 48

Ghandour, G., 435

Gibbs, R.A., 29, 1074

Gibson, K., 531

Gibson, M., 234

Giddings, M.C., 644

Gilbert, D.A., 69

Gingeras, T.R., 435

Giraud-Delville, C., 901

Glass, J.I., 557

Glöckner, G., 1060

Goodman, L., 997

Goodman, N., 509

Gordon, D., 195

Gordon, L.A., 791

Gorrell, J.H., 29, 1074

Goto, S., 203

Grant, O., 741

Green, P., 175, 186, 195, 414

Grenet, J., 929

Greystrong, J., 531

Groet, J., 385

Gruber, I., 929

$\mathrm{Gu}, \mathrm{Z}$., 748

Guénet, J.-L., 531 


\begin{tabular}{|c|c|c|c|}
\hline Guex, N., 348 & Jonassen, I., 1202 & Liu, P.P., 1172 & Myers, B.C., 1113 \\
\hline Gumucio, D., 1172 & Jones, T.A., 385 & Livak, K.J., 549 & Newell, W., 493 \\
\hline funderson, K.L., 1142 & Kadotani, H., 427 & Lockhart, D.J., 1142 & Ng, W.V., 1131 \\
\hline Gururajan, R., 929 & Kahan, T., 1172 & Lopez, F., 524 & Ni, L., 57 \\
\hline Guyer, M., 413 & Kanehisa, M., 203, 1048 & Loraine, A.E., 291 & Nierras, C.R., 419 \\
\hline Gyарау, G., 1216 & Karlsson, M., 1085 & Loretz, C., 1131 & Nilsson, M., 769 \\
\hline Hall, B., 1131 & Kashuk, C., 111 & Lu, J., 29 & Nižetić, D., 385 \\
\hline Halleck, M.S., 354 & Kastner, D.L., 1172 & Lyall, A., 493 & Nizetic, D., 631 \\
\hline Hamon, M., 1172 & Kawaguchi, T., 509 & Lynch, E.D., 306 & Nowak, N.J., 48, 57 \\
\hline Hannappel, U., 842 & Kawamoto, K., 666 & Mahtani, M.M., 100 & Nystuen, A.M., 377 \\
\hline Hanson, R.E., 479 & Kelley, M., 531 & Manger, I.D., 18 & Oaks, F., 69 \\
\hline Hartzell, G., 967 & Kelsey, G., 881 & Mansfield, E., 1172 & O’Brien, K., 741 \\
\hline Hayes, W.S., 1154 & Kenmochi, N., 509 & Mardis, E.R., 543 & Oefner, P.J., 848 \\
\hline Haynes, A., 531 & Kepler, T.B., 124 & Marklund, L., 399 & Oeltjen, J.C., 29 \\
\hline Hazan, J., 1216 & Kidd, V.J., 929 & Marklund, S., 826, 951 & Ogata, H., 203 \\
\hline Hehl, A., 18 & Kijas, J., 826 & Marquardt, A., 48 & Oliver, J.L., 916 \\
\hline Heiner, C.R., 557 & Kim, J.M., 464 & Marquette, C., 1216 & Olson, M., 414 \\
\hline Hejtmancik, F., 57 & Kim, S.Y., 404 & Marra, M., 18 & Orias, E., 91 \\
\hline Hellsten, E., 724 & King, M.-C., 306 & Marth, G., 260 & Oustry, A., 901 \\
\hline Helt, G.A., 291 & Kloos, D.-U., 842 & Martin, J., 590 & Overton, G.C., 18, 234, \\
\hline Herberg, J.A., 631 & Koi, M., 666 & Martin, S.A., 146 & 362 \\
\hline Herring, C.D., 673 & Koonin, E.V., 779, 1038 & Mason, R., 631 & Page, D.C., 509 \\
\hline Hide, W., 276 & Korenberg, J.R., 940 & Matesic, L.E., 940 & Pallavicini, A., 817 \\
\hline Higgins, M.J., 57 & Kouprina, N., 666 & Mavel, D., 1216 & Panussis, D.A., 543 \\
\hline Hillier, L., 18, 175, 260, & Krizman, D., 1172 & Mazzarella, R., 1007 & Paternotte, C., 1216 \\
\hline 748,975 & Kubota, T., 146 & McCombie, W.R., 306 & Paterson, A.H., 479 \\
\hline Hodgson, D., 975 & Kwok, P.-Y., 549, 748, & McCready, P., 791 & Peitsch, M.C., 348 \\
\hline Hoffman, R., 404 & 769 & McGrane, R.M., 543 & Peltonen, L., 724 \\
\hline Hoffman, S.M., 791 & Lacey, T., 531 & McKee-Johnson, J.W., & Persson, H., 951 \\
\hline Hoheisel, J.D., 809 & Lahti, J.M., 929 & 940 & Pettersson, U., 809 \\
\hline Holodniy, M., 435 & Lamerdin, J.E., 791 & McKie, J.M., 834 & Pickard, B., 881 \\
\hline Hood, L., 1131 & Landegren, U., 769 & McMurray, A.A., 562 & Pilgrim, D., 1192 \\
\hline Hood, L.E., 1022 & Lanfranchi., G., 817 & McQueen, H.A., 621 & Piper, M.B., 599 \\
\hline Hopkins, K.A., 211 & Lange, D., 826 & Melanitou, E., 608 & Poirier, C., 531 \\
\hline Horelli-Kuitunen, N., & Lange, K., 222 & Menchen, S., 69 & Poirot, O., 524 \\
\hline 724 & Larionov, V., 666 & Michelmore, R.W., 1113 & Polley, A., 842 \\
\hline Horrigan, S.K., 404 & Lathrop, M., 608 & Mignot, E., 427 & Potier, M.-C., 385 \\
\hline Huang, B., 146 & Lauster, R., 124 & Miller, C.L., 737 & Pradhan, D., 354 \\
\hline Huang, X.C., 1142 & Lavedan, C., 871 & Miller, W., 29, 967, 1074 & Price, H.J., 479 \\
\hline Hudson, T.J., 509 & Ledbetter, D.H., 146 & Mitchison, N.A., 124 & Pruitt, K.D., 4, 86, 170, \\
\hline Humphray, S.J., 631 & Lee, I.Y., 1022 & Mjaatvedt, A.E., 940 & $334,422,572,686$, \\
\hline $\begin{array}{l}\text { Hunicke-Smith, S.P., } \\
\quad 848\end{array}$ & $\begin{array}{l}\text { Lee, M.K., } 306 \\
\text { Lehrach, H., 385, } 493\end{array}$ & $\begin{array}{l}\text { Mohrenweiser, H.W., } \\
791\end{array}$ & $\begin{array}{l}763,864,1000, \\
1109\end{array}$ \\
\hline Hunkapiller, K.L., 557 & Leonard, C.J., 1038 & Moller, M., 826 & Prusiner, S.B., 1022 \\
\hline Huo, Y.K., 940 & Lewis, S., 291 & Montagutelli, X., 531 & Puffenberger, E.G., 111 \\
\hline Ivens, A.C., 135 & Lewis, S.M., 135 & Morris, M.S., 1142 & Quail, M.A., 562 \\
\hline Ives, J.H., 385 & Li, Q., 748 & Mott, R., 260 & Ragoussis, J., 631 \\
\hline Jacob, H.J., 268 & Li, W., 916 & Moyzis, R.K., 1172 & Rampoldi, L., 817 \\
\hline Jalanko, A., 724 & Linblad, K., 1085 & Mundy, C., 531 & Rapp, J.P., 711 \\
\hline Janitz, M., 124 & Lindgren, G., 951 & Muselet, D., 1216 & Raudsepp, T., 577 \\
\hline Jeon, J.-T., 399 & Ling, H.-Q., 842 & Mushegian, A.R., 590 & Rayner, S., 741 \\
\hline Jiang, J., 268 & Lipshutz, R.J.,11142 & Mutirangura, A., 146 & Reeves, R.H., 940 \\
\hline Johnston, S.L., 673 & Liu, J., 1172 & Muzny, D., 1074 & Reik, W., 881 \\
\hline Joly, F., 608 & Liu, L.X., 590 & Muzny, D.M., 29 & Rhodes, M., 531 \\
\hline
\end{tabular}




\begin{tabular}{|c|c|c|}
\hline Riblet, R., 673 & Simon, D., 531 & Vega-Czarny, N., 1216 \\
\hline Richards, N., 1172 & Sinsheimer, J.S., 222 & Vilo, J., 1202 \\
\hline Richards, R.I., 1172 & Siriaco, G., 621 & Voit, T., 1216 \\
\hline Richterich, P., 251 & Sjöberg, K., 1085 & Voytas, D.F., 464 \\
\hline Ricke, D.O., 1172 & Slagel, J., 1131 & Wadey, R.B., 834 \\
\hline Rifkin, L.L., 543 & Small, P.M., 435 & Walder, R., 711 \\
\hline Rivera, A., 48 & Smilinich, N.J., 57 & Walker, D.R., 779 \\
\hline Rönnstrand, L., 826 & Smit, A.F.A., 1022 & Walker, J., 531 \\
\hline Robertson, H.M., 449 & Smith, D.F., 135 & Wan, K.-L., 18 \\
\hline Robertson, J.M., 69 & Smith, L.M., 644 & Wang, E., 435 \\
\hline Rodriguez-Martinez, H., & Smith, R.J.H., 57 & Wang, H., 276 \\
\hline 826 & Smith, T.M., 1131 & Wang, K., 1022 \\
\hline Roe, B., 331 & Snider, J.E., 543 & Ward, T., 741 \\
\hline Roos, D.S., 18 & Sood, R., 1172 & Warner, J.R., 419 \\
\hline Rosenberg, H.F., 599 & South, A.P., 385 & Waterston, R., 18 \\
\hline Rosenblum, B.B., 69 & Stelly, D.M., 479 & Watson, P., 531 \\
\hline Rosenthal, A. 1060 & Stöhr, H., 48 & Weber, B.H.F., 48 \\
\hline Rozen, S., 509 & Stolovitzky, G., 916 & Weber, J., 1060 \\
\hline Rubin, G.M., 291, 967 & Stone, E.M., 377 & Weiss, K.M., 691 \\
\hline Rudnicki, D., 1216 & Straw, R., 531 & Weissenbach, J., 1216 \\
\hline Rue, E.E., 940 & Strong, J.T., 543 & Wendel, J.F., 479 \\
\hline Salonen, T., 724 & Sulston, J.E., 562 & Wendl, M.C., 175, 975 \\
\hline Samson, D., 1216 & Sutcliffe, J.S., 146 & Wenz, H.-M., 69 \\
\hline Sandberg, K., 951 & Sutherland, H.F., 834 & Westaway, D., 1022 \\
\hline Sandgren, B., 951 & Swiderski, R.E., 377 & Westbrook, C.A., 404 \\
\hline Sandmeyer, S., 416 & Taft, A.S., 41 & Weston, P., 531 \\
\hline Scambler, P.J., 834 & Taillon-Miller, P., 748 & Westphall, M., 644 \\
\hline Schadt, E.E., 222 & Tammi, M., 809 & Wettstein, P.J., 673 \\
\hline Schaffer, A.A., 211 & Tanaka, T., 509 & Wheelan, S.J., 168 \\
\hline Schalling, M., 1085 & Taylor, C.L., 834 & Wike, C., 69 \\
\hline Schattevoy, R., 1060 & Taylor, D., 531 & Willard, H.F., 100 \\
\hline Scheibler, D., 69 & The Sanger Centre, 1097 & Williamson, P., 354 \\
\hline Scherer, S., 1060 & The Washington Uni- & Wilson, R., 543 \\
\hline Scherthan, H., 577 & versity Genome Se- & Wiltshire, T., 940 \\
\hline Schibler, L., 901 & quencing Center, & Winick, J.D., 985 \\
\hline Schimenti, J., 698 & 1097 & Womack, J.E., 731 \\
\hline Schlegel, R.A., 354 & Thelaus, J., 1085 & Wood, G., 1172 \\
\hline Schlessinger, D., 1007 & Thierry-Mieg, J., 260 & Wu, J., 644 \\
\hline Schug, J., 234 & Thompson, R.C., 737 & Yang, Y.-P., 731 \\
\hline Schwartz, S., 29 & Thorstenson, Y.R., 848 & Yao, H., 1022 \\
\hline Searle, J.B., 1 & Tiso, N., 817 & Yaspo, M.-L., 385 \\
\hline Searls, D.B., 362 & Tomii, K., 1048 & Ying, L., 377 \\
\hline Senger, G., 631 & Toppo, S., 817 & Zaks, N., 1172 \\
\hline Seto, J., 1022, 1131 & Tran, A.-N., 809 & Zander, C., 1085 \\
\hline Settles, A.M., 83 & Tripodis, N., 631 & Zhang, L., 135 \\
\hline Severin, J., 644 & Trowsdale, J., 631 & Zhang, M.Q., 319 \\
\hline Severson, D.W., 41 & Tsui, L.-C., 1060 & Zhang, Q.-Y., 711 \\
\hline Shafran, N., 1172 & Ukkonen, E., 1202 & Zhang, Z., 29, 967 \\
\hline Shaw, S.H., 111 & Vaiman, D., 901 & Zhao, X.-p., 479 \\
\hline Sheffield, V.C., 377 & Valle, G., 817 & Zimbello, R., 817 \\
\hline Shows, T.B., 48, 57 & Van Broeckhoven, & \\
\hline Si, Y., 479 & & \\
\hline Sibley, L.D., 18 & Vanguri, S., 464 & \\
\hline Simionati, B., 817 & Vedula, A., 1172 & \\
\hline
\end{tabular}




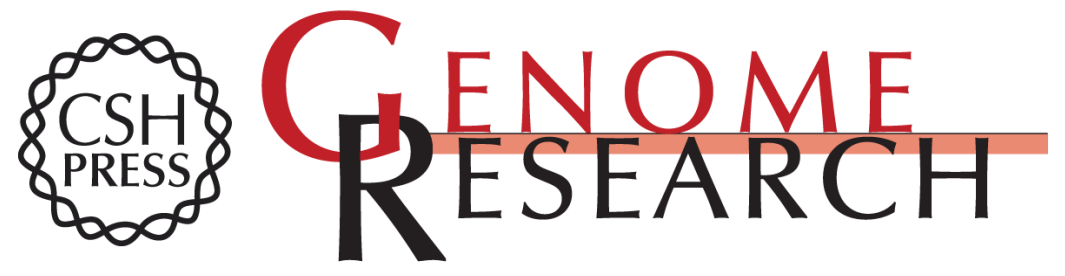

\section{A DNA Polymorphism Discovery Resource for Research on Human Genetic Variation}

Francis S. Collins, Lisa D. Brooks and Aravinda Chakravarti

Genome Res. 1998 8: 1229-1231

Access the most recent version at doi:10.1101/gr.8.12.1229

Related Content Errata for vol. 8, p. 1229

Genome Res. February, 1999 9: 210

References This article cites 14 articles, 11 of which can be accessed free at: http://genome.cshlp.org/content/8/12/1229.full.html\#ref-list-1

Articles cited in:

http://genome.cshlp.org/content/8/12/1229.full.html\#related-urls

\section{License}

Email Alerting

Receive free email alerts when new articles cite this article - sign up in the box at the Service top right corner of the article or click here.

\section{Affordable, Accurate Sequencing.}

